\title{
Informální učení v kariéře žen
}

\author{
Lenka Hloušková \\ Masarykova univerzita, Filozofická fakulta, Ústav pedagogických věd
}

Redakci zasláno 14. 8. 2012 / upravená verze obdržena 5. 5. 2013 / k uveřejnění přijato

21. 5.2013

\begin{abstract}
Abstrakt: Cílem př́spěvku je popsat, jak informální učení ovlivňuje kariérový rozvoj žen. Odpovědi na uvedenou otázku vychází z kvalitativního šetření, které bylo součástí výzkumu podle zadání Centra Euroguidance ČR s názvem: Potřeby dospělých ve vztahu k ř́zení své kariéry a možnosti jejich uspokojování prostrednictvím služeb kariérového poradenství. Kvalitativní šetření bylo realizováno v duchu biografického výzkumu s využitím metody životního příběhu a pro účely tohoto příspěvku byl sestaven výzkumný vzorek sedmi žen různého věku, stejného stupně vzdělání, $\mathrm{s}$ minimálně jednoletou zkušeností $\mathrm{v}$ zaměstnání a s rủznými typy změn $\mathrm{v}$ kariéře. Z dat vyplývá, že se ženy učí bud' v důsledku tlaku určité situace, nebo tzv. do zásoby. Pokud se ženy učí v důsledku tlaku konkrétní situace, informální učení představuje nástroj uspokojování různých potřeb vnímaných jako deficit. Ženy, které se učily výhradně v důsledku tlaku aktuálních situací, obvykle neplánovaly svůj kariérový rozvoj v dlouhodobé perspektivě a informální učení se z hlediska řízení kariérového rozvoje stává nástrojem změny aktuálního stavu. V př́ípadě, že se ženy učí tzv. do zásoby, snaží se uspokojit potřeby, které lze podle Maslowovy pyramidy potřeb zahrnout do tzv. seberealizačních potřeb. Tyto ženy plánovaly svůj kariérový rozvoj $\mathrm{v}$ dlouhodobém horizontu a informální učení lze v jejich př́ípadech považovat za přímý nástroj jejich kariérového rozvoje.
\end{abstract}

Klíčová slova: informální učení, kariéra, kariérový rozvoj, životní příběh

Učení bývá v českém pedagogickém výzkumu stále spojováno spíše se žáky a studenty vzdělávacích zařízení než s každodenním životem dospělých, a to navzdory tomu, že dospělí se díky učení přizpůsobují novým situacím, pomaleji stárnou a vytvářejí si př́ležitosti ke svému rozvoji. Učení jako aktivita jedince, $v$ jehož průběhu i důsledku jedinec mění své poznatky, formy chování a způsoby činnosti, vlastnosti i obraz sebe sama směrem k rozvoji a vyšší účinnosti (Kulič, 1992, s. 32), se vlivem konceptu celoživotního učení stává novodobým imperativem, o němž s jistou nadsázkou platí, že ovlivňuje naše životy. Koncept celoživotního učení bývá obvykle strukturován na formální vzdělávání, neformální vzdělávání a informální učení.

Informální učení dospělých je v českém prostředí zkoumáno především kvantitativními metodologickými postupy (Rabušicová \& Rabušic, 2008; Vzdělá- 
vání..., 2012) a snad až na výjimku tématu mezigeneračního učení v rodině (Rabušicová, Kamanová, \& Pevná, 2011) je pragmatické využití informálního učení v životě dospělých zkoumáno sporadicky. $V$ textu se zaměřím na jedno z takových „využití“ a ptám se, jak se procesy informálního učení podílejí na řízení kariéry (kariérovém rozvoji). Význam informálního učení v kariérovém rozvoji budu sledovat na účelově sestaveném výzkumném vzorku sedmi dospělých žen a odpověd' na otázku, jak procesy informálního učení vstupují (či ovlivňují) kariérový rozvoj žen, budu sledovat skrze tři dílčí otázky: kdy (v jakých obdobích) se ženy učí, co (jaké obsahy) se ženy učí a jak se ženy učí (jaké taktiky a strategie učení využívají).

\section{Teoretická východiska}

Téma informálního učení v kariéře dospělých (žen) integruje dvě teoretická východiska: informální učení a kariérový rozvoj. Informální učení jako „proces získávání vědomostí, osvojování si dovedností, postojů a kompetencí z každodenních zkušenostía činností v práci, rodině a ve volném čase" (Průcha \& Veteška, 2012, s. 130) zahrnuje samostudium (sebevzdělávání) v různých prostředích, tj. intencionální učení, a učení v průběhu každodenních aktivit vyznačujících se spontánností, nezáměrností až bezděčností, tj. incidentální učení. Informální učení není institucionálně organizováno, probíhá v určitých situacích nebo tehdy, když dospělí naplňují své životní role. Je založeno na zkušenosti, je produktem pobývání jedince v konkrétním sociálním prostředí a v mnoha př́padech ho lze vnímat jako vedlejší produkt jiné činnosti, př́́padně jako součást reakcí jedince na danou situaci. Pro informální učení je typický implicitní charakter, což znamená, že učící se jedinec si často ani neuvědomuje rozsah a intenzitu svého učení. V průběhu informálního učení se uplatňují spíše induktivní postupy, chybí řízená zpětná vazba a zpětnou vazbu zajištují činnosti nebo reakce ostatních lidí v dané situaci (Hager, 2001; Marinková \& Stretti, 2009; Průcha \& Veteška, 2012; Rabušicová \& Rabušic, 2008). Informální učení neprobíhá v životě dospělých izolovaně, ale lze předpokládat, že probíhá i během neformálního a formálního vzdělávání. Informální učení v rámci neformálního a formálního vzdělávání ale nebude předmětem tohoto pojednání.

Jak již bylo zmíněno, obsah a postupy informálního učení nebyly až na výjimky (např. Rabušicová \& Rabušic, 2008; Rabušicová, Kamanová, \& Pevná, 2011) u českých dospělých popsány. Proto se budu inspirovat $v$ různých teoriích učení, které jsou typicky spojovány s učením se dospělých, respektují 
základní princip situovaného učení (situated learning ${ }^{1}$ ) a vysvětlují učení na pozadí získávání zkušeností (experiential learning). Nabývání zkušeností lze popsat jako učení prostřednictvím vlastní činnosti (Dewey), prostřednictvím reflexe činnosti nebo zkušenosti (Kolb, Jarvis), prostřednictvím pozorování chování druhých a důsledků pozorovaného chování (Bandura), vlivem interakce s prostředím (Illeris) a řadou jiných způsobů (Hartl \& Hartlová, 2010, s. 632-641; Illeris, 2009; Pätzold, 2011).

Detailnější vhled do způsobů učení dospělých přinesly mj. i výzkumy individuálních specifik učení. Tyto výzkumy dokládají, že se dospělí učí jinak v závislosti na tom, co se učí, v jakém prostředí se učí (např. ve vzdělávacích zařízeních, na pracovišti), ale i díky tomu, jaké postupy při učení preferují (styly učení), s jakou zodpovědností se staví k učení, jak reflektují své i přejaté zkušenosti nebo jak jsou schopni reflektovat své potřeby a podle nich si vybrat metody, prostředky, tempo i čas učení (self-directed learning; srov. Löwe, 1977; Mareš, 1998). Individualizovaný pohled na učení dospělých je obvykle svázán s motivy učení, které jsou v teoriích motivace učení ztotožňovány s potřebami (Nakonečný, 1996, s. 29, s. 52-54; Van Dellen, 2012, s. 19).

Potřeby, které jsou dospělými prožívány jako rozdíl mezi aktuálním a žádoucím stavem narušujícím vnitřní rovnováhu jedince (Hartl \& Hartlová, 2010 2010, s. 433; Palán, 2002, s. 234), jsou v kontextu teorie motivace učení vymezovány jako výchozí stav, který se během získávání nových zkušeností zpředmětňuje (jedinec nachází objekt učení). Poté, co jsou potřeby zpředmětněny, si jedinec vytváří instrumentální vzorce chování, které se stávají nástrojem uspokojování potřeb (Nakonečný, 1996, s. 29). Takto vymezené potřeby považuji i za výchozí stav informálního učení (subjektivně pocit’ované důvody učení) a instrumentální vzorce chování ztotožňuji bud' s taktikami v př́ípadě bezděčného, incidentálního učení, nebo se strategiemi, které představují osobitý způsob realizace plánu učení v případě intencionálního učení (srov. Mareš, 1998, s. 58).

Druhé teoretické východisko se týká kariéry a kariérového rozvoje. Při vymezování kariérového rozvoje vycházím z humanistických, konkrétně pak konstruktivistických (systemických a narativních) proudů vymezování kariéry, které vyzdvihují dynamičnost a subjektivitu kariéry. Základním předpokladem takto vymezovaných typů kariér (např. kariéra bez hranic, proteovská kariéra) je, že každý jedinec si kariéru tvoří sám na základě svých zkuše-

1 Učení je funkcí konkrétní aktivity, kontextu a kultury, v nichž učení probíhá. Základním principem tohoto učení je sociální interakce a komunikace. 
ností a v kontextu (limitech) svého náhledu na svět. $V$ návaznosti na uvedená vymezení kariéry je kariérový rozvoj definován jako zodpovědné řízení kariéry (života, učení a práce) jedincem, konkrétně celoživotní proces růstu jedince skrze učení, práci a realizaci osobního potenciálu (např. Australian..., 2006; Jarvis, 2003; Kirovová, 2007; Toric, 2007). Z tohoto úhlu pohledu lze informální učení chápat jako jeden z nástrojů řízení kariéry, tj. kariérového rozvoje. Vzhledem $\mathrm{k}$ tomu, že v textu budu charakterizovat informální učení na účelově sestaveném vzorku žen různého věku (viz dále), dá se předpokládat, že respondentky budou svůj kariérový rozvoj vnímat rozdílně, a to bud' v duchu uvedeného (soudobého) vymezení kariéry, nebo v duchu tradičního vymezení kariéry jako profesní dráhy. Tradiční kariéra v podobě profesní dráhy se vyznačuje strukturovaným (obvykle lineárním) průběhem s minimem změn a tendencí zakotvit kariérový rozvoj v konkrétní profesi. Zodpovědnost za řízení profesní dráhy je spojována spíše se zaměstnavateli než s jedinci samotnými (srov. Kirovová, 2007). Do takto vymezeného kariérového rozvoje se „nepočítají“ období, kdy jedinci ztrácí uplatnění na trhu práce, protože spolu se ztrátou pracovního uplatnění jedinec ztrácí i možnosti kariérového rozvoje. Obvykle se za tato období u žen považuje doba rodičovské dovolené nebo doba nezaměstnanosti. Předpoklad individualizovanosti a subjektivity kariérového rozvoje a s tím spojené individualizovanosti motivů učení a taktik či strategií informálního učení se projevil i v metodologii výzkumu.

\section{Metodologie výzkumného šetření}

Tato studie představuje dílčí výstup z výzkumu podle zadání Centra Euroguidance ČR s názvem: Potřeby dospělých ve vztahu $k$ ř́zení své kariéry a možnosti jejich uspokojování prostřednictvím služeb kariérového poradenství. Celý výzkum byl koncipován jako smíšený výzkum na principu simultánního modelu sběru dat (Hendl, 2005, s. 277), tj. paralelně vedle sebe probíhal sběr dat s využitím kvantitativních i kvalitativních postupů. Kvalitativní šetření, z něhož vychází tento text, bylo designováno jako biografický výzkum a sběr dat proběhl v duchu metody životního příběhu.

Cílem kvalitativního šetření v rámci uvedeného výzkumu bylo zmapovat potřeby dospělých ve vztahu k řízení kariéry u vybraných skupin dospělých a tento cíl byl strukturován na tři dílčí cíle:

- zmapovat dosavadní vývoj kariéry s důrazem na naplňování životních cílů; 
- identifikovat aktuální možnosti, bariéry a schopnosti jedince řídit svoji kariéru;

- popsat potřeby zkoumaných osob ve vztahu k řízení kariéry.

Hlavní metodou sběru dat byly dva typy rozhovorů: biografický (narativní) rozhovor a polostrukturovaný (epizodický) rozhovor (Hendl, 2005, s. 131, s. 176-177). První - biografický - rozhovor mapoval dosavadní vývoj kariéry s důrazem na naplňování životních cílů (přání) a s ohledem na aktuální možnosti, bariéry a schopnosti jedince řídit svou kariéru. Na základě předběžných analýz biografických rozhovorů byl s každým respondentem veden druhý - polostrukturovaný - rozhovor na témata, která byla pro daného respondenta významná a týkala se řízení jeho kariéry. Sběr dat probíhal od října do prosince roku 2011 prostřednictvím speciálně proškolených pěti tazatelů ${ }^{2}$.

Výběr respondentů pro účely kvalitativního šetření probíhal jako teoreticky zaměřený výběr. $S$ ohledem na časové a finanční možnosti zadavatele výzkumu byl rozsah vzorku předem znám (celkem 30 respondentů). Vlastní výběr respondentů probíhal ve dvou fázích. Nejdř́ve bylo nadefinováno pět skupin dospělých podle charakteristik, které ztěžují, nebo naopak usnadňují začlenění jedince na trh práce. Mezi uvedené charakteristiky patří: věk, pohlaví, dosažený stupeň vzdělání a skupina zaměstnání podle hlavních tříd Klasifikace zaměstnání (Klasifikace..., 2010). Na základě těchto charakteristik bylo vymezeno pět skupin dospělých:

- dospělí ve věku 18-49 let se základním vzděláním, kteří nejsou příslušníky žádné z etnických minorit žijících v ČR a na trhu práce nacházejí uplatnění v kategorii bez kvalifikace;

- muži ve věku 50+, vyučení, vykonávající dělnické profese;

- dospělí ve věku 30-49 let se středoškolským vzděláním, kteří jsou zaměstnáni na pracovních pozicích v rámci kategorie nižších administrativních pracovníků;

- ženy ve věku 25-35 let se středoškolským vzděláním, aktuálně na rodičovské dovolené, které byly před nástupem na rodičovskou dovolenou zaměstnány v oblasti služeb;

2 Součástí školení tazatelů bylo i průběžné srovnávání vlivu různých tazatelů na respondenty, čímž byly eliminovány základní chyby při sběru dat, v jejichž důsledku dochází ke zkreslení dat. 
- ženy vysokoškolačky bezdětné ve věku 20-30 let, které se připravují na vybranou profesi a $v$ průběhu vysokoškolského studia jsou zaměstnány na částečný úvazek.

Nejdříve byli respondenti do jednotlivých skupin vybíráni jako tzv. zajímavé případy (Hendl, 2005, s. 152) a na základě analýz prvních rozhovorů výběr pokračoval tak, aby každá skupina respondentů byla co nejvíce homogenní. Mezi dalšími kritérii výběru se tak objevila např. zkušenost s nezaměstnaností, počet změn v kariéře, předčasný odchod ze středoškolského studia, aktuálnost návratu do zaměstnání po rodičovské dovolené, studium oborủ na vysoké škole, které jsou předpokladem pro výkon práce sociálního pracovníka. Vzhledem $\mathrm{k}$ předem jasnému počtu respondentů $\mathrm{v}$ každé skupině (šest respondentů) není možné doložit teoretickou saturaci výzkumného vzorku.

Z předběžných analýz všech 60 rozhovorů vyplynulo, že informální učení je procesem, který se podílí na řízení kariéry v rủzných obdobích kariérového rozvoje, což bylo nejvíce patrné u žen např́ič všemi pěti uvedenými skupinami. Tato skutečnost byla impulzem k podrobnějšímu prozkoumání charakteristik informálního učení žen a stanovení tří následujících otázek:

- v jakých obdobích života se ženy informálně učily;

- jaké obsahy si ženy spojují s informálním učením;

- jaké taktiky či strategie ženy uplatňují, když se informálně učí.

Uvedené otázky, empiricky doložené odlišnosti $\mathrm{v}$ učení se dospělých a odlišnosti $\mathrm{v}$ ř́zení kariéry se staly východiskem pro stanovení kritérií výběru respondentek do účelově sestaveného výzkumného vzorku pro tento text. Z výzkumů specifik učení se dospělých vyplývají čtyři kritéria: pohlaví, dosažené vzdělání, aktuální zaměstnání a částečně i věk ${ }^{3}$. Z hlediska řízení

3 Z výzkumů účasti dospělých na informálním učení vyplývá, že vzdělanější a zaměstnaní dospělí se účastní informálního učení častěji než lidé se základním vzděláním a lidé ekonomicky neaktivní nebo nezaměstnaní (Rabušicová \& Rabušic, 2008; Vzdělávání..., 2012). Z hlediska pohlaví nejsou údaje o převažující účasti žen na informálním učení ve všech měřeních shodné, což lze přičíst odlišnostem v operacionalizaci konstruktu účasti na informálním učení (Rabušicová \& Rabušic, 2008; Vzdělávání..., 2012). Naproti tomu výzkumy stylů učení u dospělých relativně dobře rozkryly rozdíly mezi strategiemi učení u mužů a žen (Mareš, 1998, s. 119-121). Dále bylo prokázáno, že se lépe učí nadaní a vzdělanější a aktuálně motivovaní osobním významem než motivovaní receptivně pasivním postojem (Löwe, 1977). Z časového hlediska platí, že čím delší je přestávka v učení, tím větší problém bývá znovu se vrátit k učení (Hartl \& Hartlová, 2010, s. 232). Věková specifika při učení se dospělých nebyla dosud přesvědčivě prokázána, ale věk v souvislosti s dalšími faktory jako např. dosažené vzdělání, druh povolání a situačním kontextem může věkové rozdíly zvýraznit (Löwe, 1977; Mareš, 1998). 
kariéry vystupují do popředí dvě kritéria: příležitosti k řízení kariéry, které jsou $\mathrm{v}$ našem př́padě vymezeny celkovou délkou zaměstnání $\mathrm{v}$ rozsahu minimálně jednoho roku, a prožití minimálně dvou změn v kariéře, které byly subjektivně hodnoceny jako významné (opuštění trhu práce v důsledku mateřské/rodičovské dovolené a v důsledku nezaměstnanosti). Na základě uvedených šesti kritérií byl sestaven vzorek sedmi žen různého věku, stejného stupně dosaženého vzdělání, aktuálně zaměstnaných nebo samostatně výdělečně činných $\mathrm{s}$ minimálně jednoletou zkušeností $\mathrm{v}$ zaměstnání a s různými typy změn v dosavadní kariéře (viz tabulka 1).

Tabulka 1

\section{Charakteristika výzkumného vzorku}

\begin{tabular}{|c|c|c|c|c|}
\hline $\begin{array}{l}\text { Fiktivní } \\
\text { jméno }\end{array}$ & Věk & $\begin{array}{l}\text { Nejvyšší dosažené } \\
\text { vzdělání }\end{array}$ & $\begin{array}{l}\text { Vývoj kariéry/ Přibližná délka zaměstnání } \\
\text { v průběhu kariéry }\end{array}$ & $\begin{array}{l}\text { Délka } \\
\text { MD/RD }\end{array}$ \\
\hline Veronika & 49 let & $\begin{array}{l}\text { Úplné střední } \\
\text { odborné vzdělání }\end{array}$ & $\begin{array}{l}\text { Studium SŠ, 1. zaměstnání a v průběhu } \\
\text { 1. zaměstnání dokončení SOŠ, povy̌šení, } \\
\text { v průběhu povy̌šení zkoušky z CJ, NJ na } \\
\text { dálnopis, MD, návrat do 1. zaměstnání, MD, } \\
\text { nezaměstnanost }{ }^{4}, 2 \text { zaměstnání, přesun na } \\
\text { jiné oddělení, přesun na jiné pracoviště. } \\
\text { Celková délka zaměstnání cca } 29 \text { let. }\end{array}$ & 5,5 let \\
\hline Vlasta & 49 let & $\begin{array}{l}\text { Úplné střední } \\
\text { odborné vzdělání }\end{array}$ & $\begin{array}{l}\text { Studium SOŠ, 1. zaměstnání, MD, } \\
\text { nezaměstnanost, v domácnosti, } \\
\text { 2. zaměstnání, nezaměstnanost a v průběhu } \\
\text { nezaměstnanosti rekvalifikační kurz, } \\
\text { 3. zaměstnání, povýšení, v průběhu } \\
\text { 3. zaměstnání studium VŠ. } \\
\text { Celková délka zaměstnání cca } 25 \text { let. }\end{array}$ & 5 let \\
\hline Růžena & 39 let & $\begin{array}{l}\text { Úplné střední } \\
\text { všeobecné } \\
\text { vzdělání }\end{array}$ & $\begin{array}{l}\text { Studium gymnázia, nezaměstnanost } \\
\text { a v jejím průběhu studium nultého ročníku } \\
\text { VŠ, 1. zaměstnání, v průběhu prvního } \\
\text { zaměstnání získává řidičský průkaz, } \\
\text { 2. zaměstnání, MD, návrat po RD zpět do } \\
\text { 2. zaměstnání, změna pracovní pozice. } \\
\text { Celková délka zaměstnání cca } 18 \text { let. }\end{array}$ & 3 roky \\
\hline Renata & 33 let & $\begin{array}{l}\text { Úplné střední } \\
\text { odborné vzdělání }\end{array}$ & $\begin{array}{l}\text { Studium SOU, 1. zaměstnání, } 2 \text {. zaměstnání } \\
\text { a v průběhu } 2 \text {. zaměstnání získání maturity, } \\
\text { MD/RD, 3. zaměstnání. } \\
\text { Celková délka zaměstnání cca } 7 \text { let. }\end{array}$ & 5,5 let \\
\hline
\end{tabular}

4 Za nezaměstnanost je $\mathrm{v}$ textu považováno období, kdy je jedinec evidován na úřadě práce, aktivně hledá práci a tato doba trvá minimálně jeden měsíc. 
Tabulka 1

Pokračování

\begin{tabular}{|c|c|c|c|c|}
\hline Romana & 31 let & $\begin{array}{l}\text { Úplné stř̌ední } \\
\text { odborné vzdělání }\end{array}$ & $\begin{array}{l}\text { Studium SOŠ, brigády, nezaměstnanost } \\
\text { a v průběhu nezaměstnanosti rekvalifikace, } \\
\text { 1. zaměstnání, MD/RD, 2. zaměstnání, } \\
\text { 3. zaměstnání, nezaměstnanost, } \\
\text { 4. zaměstnání, 5. zaměstnání. } \\
\text { Celková délka zaměstnání cca 6,5 let. }\end{array}$ & 7 let \\
\hline Dáša & 29 let & $\begin{array}{l}\text { Úplné střední } \\
\text { všeobecné } \\
\text { vzdělání }\end{array}$ & $\begin{array}{l}\text { Studium gymnázia, studium VŠ, přerušení } \\
\text { studia, } 1 \text {. zaměstnání, přesun na jiné } \\
\text { pracoviště, MD/RD a v jejím průběhu návrat } \\
\text { do studia, } 2 \text {. zaměstnání. } \\
\text { Celková délka zaměstnání cca } 1 \text { rok. }\end{array}$ & 4 roky \\
\hline Dita & 27 let & $\begin{array}{l}\text { Úplné střední } \\
\text { odborné vzdělání }\end{array}$ & $\begin{array}{l}\text { Studium SOŠ, nástup na VOŠ, ale předčasný } \\
\text { odchod, nezaměstnanost a v rámci } \\
\text { nezaměstnanosti pracovní stáž v délce } \\
1 \text { roku, jazyková škola, 1. zaměstnání, } \\
\text { 2. zaměstnání, nezaměstnanost, } \\
\text { 3. zaměstnání, MD/RD a v průběhu RD } \\
\text { práce na vedlejší pracovní poměr jako osoba } \\
\text { samostatně výdělečně činná, certifikovaný } \\
\text { kurz v oblasti živnostenského oprávnění. } \\
\text { Celková délka zaměstnání cca } 2 \text { roky a nyní } \\
\text { osoba samostatně výdělečně činná. }\end{array}$ & 3,5 let \\
\hline
\end{tabular}

Vlastní analýza dat začala rozborem biografických údajů, po němž následovala strukturní analýza (srov. Švaříček, 2007, s. 136). Výsledkem strukturní analýzy je vývoj kariéry, schematicky zachycený v tabulce 1 , a soubor témat, která se objevovala $\mathrm{v}$ jednotlivých úsecích kariéry.

Navazující tematická analýza ukázala, že některá témata jsou vázána na specifický kontext související s průběhem kariéry, jiná témata (napřs proces učení) jsou spíše situačně podmíněna a objevují se více či méně u všech respondentek. Úseky rozhovorů, které byly v průběhu tematické analýzy zařazeny pod téma informální učení, byly následně analyzovány technikou otevřeného kódování a jejím výsledem jsou odpovědi na tři otázky: Kdy (v jakých obdobích) se ženy učí? Co (jaké obsahy) se ženy učí? Jak se ženy učí (jaké taktiky a strategie využívají)? 


\section{Charakteristika informálního učení}

Než přistoupím k interpretaci informálního učení, považuji za důležité zmínit, že výpovědi žen byly ovlivněny zacílením rozhovorů na vývoj kariéry a kariérový rozvoj (viz výše) a v této souvislosti je pochopitelné, že informální učení ženy vztahovaly prioritně ke svému uplatnění na trhu práce. Ženy $\mathrm{v}$ rozhovorech zmiňovaly několik období, kdy si uvědomily, že se učí pro účely aktuálního nebo budoucího uplatnění na trhu práce. Jedná se o období rodičovské dovolené, období nezaměstnanosti a o dobu, kdy byly zaměstnané. V období rodičovské dovolené a v období nezaměstnanosti se ženy učily bud' tzv. do zásoby, nebo se učily za účelem řešení aktuální situace. Z hlediska obsahu informálního učení se ženy učily něco, co do té doby neznaly a neuměly, a z hlediska využití výsledků informálního učení pro účely řízení kariéry se ukázalo, že všechny ženy předpokládaly, že nové vědomosti nebo dovednosti vyústí ve změnu jejich kariéry.

\subsection{Informální učení v době rodičovské dovolené}

Ženy, které vzpomínaly na rodičovskou dovolenou jako na období, kdy se učily do zásoby a věřily, že učení jim do budoucna zajistí lepší zaměstnání, záměrně volily strategii samostudia: Protože jsem měla ještě z gymnázia knížky, tak jsem se prostě učila sama i knížky pro samouky mám. ... To jsem si vždycky dala na kočárek slovník a knížku a učívala jsem se na procházkách, popisuje Dáša. Renata při učení se do zásoby nepostupovala promyšleně a spíše situačně upřednostňovala taktiku vyhledávání sociální pomoci, která byla v jejím případě závislá na uvědomění si důležitosti sociálních kontaktů pro své učení a byla sycena potřebou sociálního kontaktu: ... když už měl člověk pocit, že je sám a třeba si i neví s něčím rady, tak šel ven, vozit kočárek a povídat s jinýma maminkama ... a víceméně každej tak nějak řešil stejný problémy, teda hlavně s tou prací.

Dita i Dáša jsou také př́́kladem, kdy se ženy učily za účelem řešení své aktuální situace, kterou prožívaly jako tíživou. Dáša se cíleně učila vlastní činností (Dewey) i díky reflektivně kognitivnímu učení (Jarvis) se naučila šít. Naučila jsem se šít, předtím jsem neuměla ušít ani utěrku (Dáša). Dita chtěla svou tíživou situaci řešit přivýdělkem z podnikatelské činnosti a při hledání předmětu svého podnikání kombinovala taktiku vyhledávání informací (sociální pomoci) a strategii samostudia. Samostudium Ditu nasměrovalo až do neformálního vzdělávání: ... pak jsem se začala koukat na internetu, kde se to dělá, jak se to dělá, že k tomu nemusís bejt kadeřnice. No a tak, jsem se začala už 
př́mo zajímat o ty kurzy. Ono těch kurzů je hodně ... Tak jsem to zkusila a ten kurz si udělala. Než ale „našla“ předmět svého podnikání, opakovaně zkoušela podnikat $v$ různých oblastech a přitom se spíše intuitivně než cíleně učila na základě zpětné vazby od okolí.

Z hlediska obsahu informálního učení je zajímavé, že se ženy učily novým profesním dovednostem, o nichž byly přesvědčeny, že by se mohly stát „hlavní" náplní práce v jejich budoucím zaměstnání nebo podnikání. Tíživá finanční situace donutila Dášu naučit se šít, což obratem využívala za účelem přivýdělku. Přitom si ale uvědomovala, že v průběhu rodičovské dovolené získala i řadu dovedností řízení kariéry (Sultana, 2012). Musela jsem se naučit si pořádně zorganizovat svůj čas, ... spolehnout se hlavně sama na sebe,... a asi bych měla i říct, že jsem i líp poznala sama sebe, co je člověk všechno schopnej stihnout a vydržet (Dáša). Dita díky absolvování vzdělávacího kurzu získala dovednost, která je nyní předmětem jejího podnikání, ale mezitím se pod tlakem tíživé finanční situace opakovaně vrhala do různých podnikatelských aktivit, které posílily její komunikační a prezentační dovednosti (tj. další dovednosti řízení kariéry) tak, že změna její osobnosti byla patrná i pro okolí: ... a když jsem to řekla mamce, tak ta mi říká, že úplně kouká, do čeho všeho se pouštím, jak jsem se změnila, že dřiv jsem byla taková tichá, nikam jsem moc nechodila, nic nepodnikala, styděla se... Já se teda taky nepoznávám.

Je zajímavé, že starší ženy obvykle dobu své mateřské dovolené nereflektovaly jako čas informálního učení, což lze jednoduše vysvětlit tím, že uplynula relativně dlouhá doba od tohoto období. Jiné možné vysvětlení je zakotveno v individuálních představách žen o svém kariérovém rozvoji. Z tohoto úhlu pohledu mohu spekulovat o tom, jestli starší ženy nevnímají svoji kariéru spíše v duchu tradičního vymezení kariéry jako profesní dráhy, do níž se „nepočítá" mateřská/rodičovská dovolená. Mateřská dovolená by pak pro tyto ženy byla přerušením kariéry. Pokud by tomu tak bylo, mohla bych tím vysvětlit i to, proč starší ženy nepovažovaly znalosti a dovednosti získané v průběhu mateřské dovolené za něco, co mohly (mohou) využít na trhu práce.

\subsection{Informální učení v období nezaměstnanosti}

Přestože se nezaměstnanost ve srovnání s rodičovskou dovolenou jeví jako velmi krátké období, i v průběhu nezaměstnanosti se ženy učily. Začátek období nezaměstnanosti byl pro respondentky spojen s evidencí na úřadu práce (dále jen ÚP) a ten všechny prožívaly negativně. V průběhu nezaměstnanosti je provázely pocity nejistoty, strachu, nepotřebnosti, ponížení, soci- 
ální závislosti, a dokonce i sociální stigmatizace, které však mizely příslibem budoucího zaměstnání.

Z dat je zřejmé, že se ženy informálně učily s cílem „vyřešit nezaměstnanost“, ale poněkud překvapivě se obsah informálního učení týkal jedné z dovedností řízení kariéry. Respondentky se totiž až $\mathrm{v}$ době nezaměstnanosti začaly učit hledat si práci: Takže člověk opravdu neví, co a jak, jakým způsobem sám sebe prezentovat ... Takže my jsme věděly, jak napsat životopis, kterej jsem samozřejmě napsanej měla, ale co dál, jakým způsobem prezentovat sebe a jak dál vlastně hledat a najít práci, tak to s náma nikdo neřešil [myšleno na SŠ i na ÚP], ř́ká Růžena. 0 tom, že dovednost hledat a najít si práci v určité míře získala každá z respondentek, svědčí fakt, že každá si dříve či později nové zaměstnání našla 5 .

Dvě ženy z uvedeného vzorku se $\mathrm{v}$ období nezaměstnanosti snažily naučit se novým profesním dovednostem v rámci rekvalifikačního kurzu (neformálního vzdělávání). Přestože informální učení v průběhu neformálního učení není předmětem tohoto textu, ve vztahu k řízení kariéry se jeví zajímavým vztah mezi řízeným učením se v průběhu (pro účely) rekvalifikace a spontánním učením se mimo rekvalifikační kurz. Jedna z žen totiž vstoupila do rekvalifikačního kurzu s představou, že získá novou profesní dovednost, která jí pomůže podnikat $\mathrm{v}$ daném oboru, a začala se informálně učit tzv. do zásoby. Postupně taktikou vyhledávání sociální pomoci při hledání nového zaměstnání, reflexí zkušeností druhých a taktikou sebereflexe zjistila, že znalosti a dovednosti získané v průběhu rekvalifikace jí k samostatnému profesionálnímu výkonu nestačí, a v důsledku toho začala nahlížet na rekvalifikační kurz jako na způsob uspokojování potřeby sociálního kontaktu.

Z dat je zřejmé, že informální učení v období nezaměstnanosti a v období rodičovské dovolené probíhá u žen velmi podobně. V obou obdobích se ženy učily proto, aby změnily svou aktuální situaci, tj. informální učení považují za instrumentální chování k uspokojení potřeb, jako je potřeba finančního zabezpečení, potřeba sociálního kontaktu, potřeba jistoty a užitečnosti. V této souvislosti je zřejmé, že informální učení je reakcí na potřeby ve smyslu nedostatku a jsou uspokojovány redukcí tohoto stavu (Nakonečný, 1996). Tyto potřeby lze podle Maslowovy hierarchické teorie potřeb považovat za tzv. deficitní motivy chování a na pozadí uspokojování deficitních potřeb

5 Vzhledem k rozsahu textu se nebudu podrobně věnovat taktikám a strategiím informálního učení, které ženy volily při osvojování si dovednosti hledání práce. 
ženy sledují jeden ze svých kariérových cílů - budoucí uplatnění na trhu práce. Uspokojení těchto potřeb je pro ženy signálem změny $\mathrm{k}$ lepšímu v jejich dosavadní kariéře. Pokud se ženy učily tzv. do zásoby, učení bylo motivováno růstovými potřebami (Maslow).

Z hlediska obsahu informálního učení se ženy v obou obdobích učí konkrétním profesním dovednostem, od nichž si slibují, že jim pomohou „uživit se“, a přitom si více či méně uvědomují, že se učí i některým dovednostem řízení kariéry, které jim očekávanou změnu v kariéře pomáhají realizovat. Mezi dovednostmi řízení kariéry se objevily: dovednost organizovat si čas, hledat si zaměstnání, využívat sociální pomoc a dovednost sebepoznání. U žen, které se učily do zásoby a byly schopny reflektovat svůj kariérový plán, se vynořuje i další obsah informálního učení - řízení kariérového rozvoje. Zajímavé je i to, že pokud se ženy rozhodly učit se profesním dovednostem za účelem řešení aktuální (tíživé) situace, obvykle využily taktiky či strategie, které je nasměrovaly do kurzů neformálního vzdělávání včetně rekvalifikace.

Rozdíl mezi učením se do zásoby a učením se za účelem řešení aktuální situace je také v dopadu informálního učení na kariérový rozvoj. V prvním př́ípadě jsou u žen patrné ambice udržet a dále rozvíjet směr kariérového rozvoje nastavený před rodičovskou dovolenou nebo před obdobím nezaměstnanosti a dá se říci, že změna je plánována v duchu: „štěstí přeje připraveným“. Pokud se ženy učily proto, aby vyřešily svou tíživou situaci, deklarují, že se kariéra plánovat nedá a rozhodují se o směru kariérového rozvoje pod vlivem oné tíživé situace. Ženy, které se učily do zásoby, reflektovaly svůj kariérový rozvoj i své plány do budoucna a učení považovaly za jeden z nástrojů svého kariérového rozvoje. Jedna z žen se v průběhu své rodičovské dovolené učila současně do zásoby i za účelem řešení tíživé situace a i když se obsahy informálního učení lišily, učení $\mathrm{v}$ obou př́ípadech vnímala jako nástroj svého kariérového rozvoje. Jinak tomu je v období zaměstnanosti.

\subsection{Informální učení v zaměstnání}

Období zaměstnanosti je na rozdíl od nezaměstnanosti relativně dlouhým obdobím, ale ženy hovořily o informálním učení jen v některých situacích. Ženy se učily $\mathrm{v}$ situacích, které pro ně představovaly změnu oproti současnému stavu, což byla situace nástupu do nového zaměstnání a změna náplně (obsahu) práce. V obou situacích se ženy učily v důsledku tlaku uvedených situací. Obsah informálního učení je také stejný - učí se reálnou nebo budoucí náplň práce, ale ženy se od sebe liší volbou taktik a strategií učení. 


\section{Nástup do zaměstnání}

Nástup do nového zaměstnání předznamenává blížící se konec nezaměstnanosti, konec rodičovské dovolené nebo předcházejícího zaměstnání a je spojen $s$ řadou často i protichůdných pocitů. Pocity žen před nástupem do nového zaměstnání oscilovaly mezi strachem z neznámého a radostí z nalezení nového zaměstnání. No měla jsem radost, že tu práci budu mít, že to bude fajn, že budu stíhat děti hlavně a že to bude dobrý, vzpomíná Renata. Blížící se termín nástupu do nového zaměstnání byl spojen spíše s nejistotou a očekáváním toho, jaké to bude, co to bude obnášet (Romana). Očekávání ale lze diferencovat podle studijní minulosti respondentek a lišila se podle toho, jestli ženy měly nastoupit do zaměstnání, které se dá označit jako uplatnění v oboru, nebo jako krok do neznáma.

$\mathrm{V}$ případě kontinuity mezi oborem středoškolského studia a novým zaměstnáním byla nejistota provázena radostí: ... poznám nový lidi, budu se dál učit nový věci tak, abych si tu práci i udržela, takže to ted' bude př́jemná změna (Dáša). Na druhou stranu byla radostná očekávání zatížena i určitou mírou profesní zodpovědnosti, což jednoduše vyjádřila Růžena: Umím toho dost, abych nezklamala? Anticipace budoucího vývoje se nesla i v duchu tradovaného rozdílu mezi školou a praxí: práce je prostě něco jinýho (Romana) a ženy skrytě doufaly, že př́ípadný rozdíl mezi školním vzděláním a praxí bude přemostěn procesem zaučení.

Pokud ženy nastupovaly do zaměstnání, o němž dosud neměly žádnou představu a náplň práce si představovaly na základě laických, často zprostředkovaných zkušeností, s blížícím se nástupem do zaměstnání jejich obavy z př́padného neúspěchu v práci rostly. Neúspěch by totiž mohl vyústit až ve ztrátu přislíbeného zaměstnání, což si žádná před nástupem do zaměstnání nechtěla připustit. Z hlediska řízení kariéry je zajímavé sledovat, jak ženy v této situaci přenášejí zodpovědnost za své učení na zaměstnavatele, což v extrémních př́ípadech vyústilo v přesvědčení, že zaměstnavatel má povinnost je po nástupu do zaměstnání zaškolit. Prostě jsem čekala, že mě nějak zaškolej nebo zaučej, ukážou nějaký ty programy, ... taky jsem neměla žádný zkušenosti, takže nás museli zaškolit, všechno ukázat (Dita). Strach z neznámého snižovalo nejen přenášení zodpovědnosti za své učení na zaměstnavatele, ale i projevovaná důvěra ze strany budoucích nadřízených nebo ujištování ze strany těch, které respondentky vnímaly jako kompetentní k posouzení jejich schopností pro výkon dané práce. 
Po nástupu do zaměstnání byly některé z respondentek zapojeny do systému firemního zaškolování, jiné byly odkázány na pověřené osoby k jejich zaučení. Ne všechny ale vnímaly zaučení jako adekvátní podporu svého informálního učení: ... tak jsme se asi čtyři dny školili s tím, že jsme tam chodili od rána skoro do noci, vždycky nám dali jeden tlustej sešit, kterej jsme si museli celej sami nastudovat, ani nám $k$ tomu nic neřekli,... pak nás posadili na linku ... a my jsme nebyli schopný nic vyř́ldit, jo nic jsme neznali (Dita). Tady [myšleno na jiném pracovišti] jsme měli školení dva měsíce, takže se nám fakt věnovali, všechno nám ukázali. Chodili jsme na ty odposlechy na linku, takže jsme si to i naposlouchali sami. Měli jsme $k$ dispozici veškerý programy, kde jsme si mohli všechno vyzkoušet a na všechno se ptát. (Dita). Z ukázek je patrné, že Dita byla opakovaně zapojena do systému firemního zaškolování, a můžeme polemizovat o tom, jestli posun ve vnímání kvality zaučení byl způsoben pouze odlišnou organizací (za)učení, nebo i změnou jejích taktik a strategií informálního učení, tj. nahrazením strategie samostudia strategií učením se z vlastních zkušeností a strategií dotazování.

Všem ostatním respondentkám ve všech zaměstnáních byla „přidělena“ osoba, která je měla zaučit, a za zmínku stojí pestrost způsobů podpory informálního učení na pracovišti. Nejjednodušší způsob zaučení spočíval v předání instrukcí a popisu očekávaného výsledku práce ze strany uvádějících: ... ukázali mi, co a jak,... kde bych dělala, co bych dělala (Romana). Poté zaučování obvykle skončilo: ... během toho prvního týdne mi řekli, co a jak, jak to má vypadat nebo jak by si to představovali (Růžena). V této situaci záleželo na vlastní aktivitě a př́ístupu k učení ze strany uváděných. Pokud ženy zaujaly aktivní postoj k učení, volily strategii dotazování. Významnou oporou v těchto případech byla osoba, které se zaučovaná mohla zeptat nebo ji požádat o radu. Musela jsem zase jenom spolíhat na tu moji kolegyni, která mně řekne, co a jak. Bez ní bych se neobešla, říká Veronika.

Časově náročnější způsob zaučení zažila ve druhém zaměstnání Veronika a Romana. Zaučování prostřednictvím zadávání dílčích úkolů a kontroly jejich plnění vedlo za určitých podmínek k pochopení pracovních úkonů, což podporovalo samostatnost při výkonu práce. Jednotlivé pracovní úkoly ženy vnímaly jako učební problém, který je potřeba samostatně vyřešit. Řekli: „udělej zápis". No tak ze začátku, protože jsem měla v hlavě těsnopis, no tak jsem si dělala poznámky těsnopisem, něco jsem si dělala tak, ... no a pak zápis. No tak jsem si něco sepsala, ted' jsem něčemu třeba nerozuměla, tak jsem šla třeba za tím ... a zeptala jsem se ho: ... „vy jste tam řekl: ,na lisovně čtverečky špatně 
jedou, co to znamená?" (Veronika). Základní podmínkou úspěchu tohoto způsobu zaučení a tím i efektivity informálního učení byla komunikace. Komunikace mezi zaučovanou a uvádějící (případně dalších spolupracovníků) ve stylu otázka-odpověd' (strategie dotazování) se spontánně rozšiřovala o udílení rad, vysvětlování: radily jsme se, proč to tak je, proč to tak třeba nemůže být (Romana), nebo komentáře $\mathrm{k}$ zadaným úkolům. Dáša žádný komentář k úkolům nedostávala, což na jednu stranu podněcovalo její učení a projevilo se to ve změně strategie učení, ... takjsem si prostě sehnala takový materiály, abych ten úkol zvládla (strategie samostudia), ale na druhou stranu absence komentářů ke splněným úkolům snižovala její motivaci k práci.

Poslední identifikovaný způsob zaučení - učení se praxí - probíhal v řádu měsíců a spočíval $\mathrm{v}$ několika krocích. Tento způsob zaučení $\mathrm{v}$ plném rozsahu prožila pouze Romana, když nastupovala do svého třetího zaměstnání. Nejdříve probíhalo pozorování výkonu práce uvádějící a společná práce s ní: chodila jsem se dívat, co a jak, ... třeba jsme si vzaly faktury zahraniční a říkala mně, na co si mám dávat pozor, co bych tam měla vyplňovat. Poté následovaly samostatné pokusy zvládnout jednotlivé pracovní úkoly: pak už jsme pracovaly tak, protože tam ten měsíc ještě byla [myšleno uvádějící], že mně dali můj vlastní počítač a ona [myšleno uvádějící] si vlastně dodělávala ještě svou práci a já jsem dělala to, co mě zaučila, tak už jsem si to prostě sama zkoušela (Romana).

Jak se ukazuje, proces informálního učení po nástupu do nového zaměstnání funguje jako učení se pod tlakem této situace. Vlastnímu procesu učení předchází reflexe pocitů, které nevyznívají tak negativně jako v př́ípadě nezaměstnanosti, ale opět vystupují do popředí tzv. deficitní motivy (Maslow). Zajímavé je, že reflexe pocitů obvykle vyústí v uvědomění si potřeby podpory učení (motiv růstu) a tato potřeba je verbalizovaná jako očekávání, že budou ženy po nástupu do nového zaměstnání zaučeny. Očekávání ohledně zaučení jsou vztažena ke konkrétním zaměstnavatelům a nejsou závislá na charakteristikách učících se žen. Každá z respondentek v průběhu své kariéry zažila různé způsoby zaučování a jediné, co při zaučování považují všechny za klíčové, je kontakt s uvádějící osobou a vytvoření si kolegiálního vztahu s ní na bázi důvěry. Pokud kontakt s uvádějící nebyl možný, nebo nefungoval, nově příchozí se snažily za účelem podpory svého učení využít kontaktů nebo vztahů s jinými spolupracovníky, čímž uspokojovaly jak deficitní potřeby ve vztahu k náplni své práce, tak potřebu svého růstu zároveň. 
To, čím se liší informální učení v důsledku tlaku tíživé situace $\mathrm{v}$ době rodičovské dovolené a po nástupu do zaměstnání, ${ }^{6}$ spočívá v přenášení zodpovědnosti za své učení. Ženy v době rodičovské dovolené zodpovědnost za své učení na nikoho nepřenášejí, ale v některých prrípadech zvolená strategie samostudia vyústí v účast na neformálním vzdělávání. Naproti tomu ženy po nástupu do zaměstnání očekávají, že jejich učení bude podporováno ze strany zaměstnavatele a pokud se vůbec uchýlí ke strategii samostudia, považují tuto volbu za volbu z nutnosti a v principu za nežádoucí.

V př́ípadě, že ženy po nástupu do zaměstnání byly ve svém informálním učení podporovány, začala se vytrácet počáteční zmatenost: takjá jsem vůbec nevěděla, kde su, co su, co mám dělat (Veronika), a měnila se ve váhavost či nejistotu při plnění jednotlivých pracovních úkolů: než bych něco udělala a nebyla si tím jistá, tak jsem radši počkala a zeptala se (Růžena). Nejistota za předpokladu přetrvávajícího odhodlání všechno se naučit brzy přerůstá v orientovanost v problematice: já myslím, že viděli, že jsem to pochopila a zvládla (Růžena). Proces informálního učení po nástupu do zaměstnání končí s přicházející profesní jistotou: a když se mi ta první zákaznice povedla na jedničku, tak jsem už pak byla v klidu (Dita). Obsahem informálního učení po nástupu do zaměstnání je vždy zvládnutí konkrétní náplně práce (profesní dovednosti), která byla v případě našich respondentek výrazně odlišná.

Z hlediska využívání taktik a volby strategií učení se zdá, že ženy volí výhradně strategie a obvykle kombinovaly strategii dotazování, strategii řešení problémů a strategii samostudia, a to s cílem udržet nastolenou změnu v kariéře. Pravděpodobně další využívanou strategií či taktikou učení je i nápodoba, která však z našich dat není přesvědčivě doložitelná. Volba jednotlivých strategií učení byla výrazně ovlivněna konkrétním pracovním prostředím, ve kterém učení probíhalo. Pokud ženy nemohly využít strategie podle „svých představ", spontánně přecházely ke strategii samostudia, v níž dominovalo učení se pokusem a omylem či učení se z vlastní zkušenosti. $V$ rámci strategie samostudia se objevila i snaha využít poznatky ze školy: dala jsem mu takový návrh, že bych tam využila nějaký metody, který jsme se učily na škole (Dáša), nebo vyhledávání informací: byla jsem schopná si kolem toho spoustu věcí nastudovat, pozjištovat, obejít (Dáša). Jak již bylo výše zmíněno, ženy považovaly volbu strategie samostudia za nežádoucí a je zajímavé, že ve všech prrí-

Z hlediska charakteru emocí jsou období rodičovské dovolené a nástup do zaměstnání srovnatelné. 
padech, kdy respondentky uvedly, že musely tuto strategii využít, v relativně krátké době nové zaměstnání opustily.

Novinky (změny) v práci

Dříve či později po zapracování se ženy ocitly v situaci změny dosavadní náplně práce. Objevila se totiž novinka, kterou se musely naučit. $\mathrm{V}$ tu chvíli ženy reflektují určité vnitřní napětí: když se zavádí novej program nebo je něco jinýho, ... tak vždycky je ten člověk tak jako v pohotovosti (Veronika), které vyústilo v uvědomování si svého postoje ke změně: jsem prostě taková, že si moc nevěř́m,... prostě nemám ráda nový věci, ne zas nějakej stereotyp, to taky ne, ale takovej ten střed (Dita), nebo: tohleto [myšleno učení se novinkám] považuju za standard, ř́ká Růžena. Poté, co ženy přijmou myšlenku změny a vyhodnotí ji ve vztahu ke svému kariérovému rozvoji, zaujmou bud' reaktivní, nebo aktivní postoj k učení.

Reaktivní postoj směruje ženy k taktikám a strategiím, které jim pomohou zvládnout konkrétní novinku či změnu. Z našeho výzkumného vzorku zaujaly reaktivní postoj k učení ty, jejichž kariérový rozvoj směřoval k udržení aktuálního zaměstnání. Tyto ženy obvykle bezděčně využívaly taktiku vyhledávání sociální pomoci, někdy i cíleně využívaly své sociální sítě nebo se učily v kurzech dalšího profesního vzdělávání. Tak nám dávali úplně novej přístroj... jako nejnovější typ a došla nabídka, že nás pozvali na školení do (město), tak jsem jela na to školení ... tak mě řekli, tady si sedneš a tady se to dělá tak, tady tak (Veronika).

Aktivní postoj, který deklaruje např. Růžena: datový schránky, to mě zajímalo, je to něco novýho, takže já jsem zas třeba byla ráda, že to padlo na mě, př́mo spouští proces informálního učení. Aktivní postoj k učení z našeho vzorku zaujaly ty, pro něž je kariérový rozvoj cílem sám o sobě, a tyto ženy $\mathrm{v}$ této situaci upřednostnily strategii samostudia. V momentě, kdy se o tom dozvím,... kdy zjistím něco, co je novýho, nebo co mě zajímá, tak v okamžiku začnu shánět. Bud' sama ... ta knihovna nebo známí, kde vím... takže volám, píšu, chatuji, až najdu, co potrebuji. No a po nocích studuji a čtu. ... okamžitě zjištujuju a snažím se zjistit, co to je, proč to je a jaký to má smysl a hlavně, jestli by to nešlo tady u nás nějakým způsobem realizovat, použít vlastně v rámci práce (Růžena). V rámci strategie samostudia se objevují postupy jako je vyhledávání informací, cílené využívání sociálních kontaktů a studium odborných textů či literatury a to vše i za pomoci informačních a komunikačních technologií. Jedno- 
značnou výhodou volby strategie samostudia v těchto př́ípadech je, že ženy zůstávají pány svého času.

To, jaký postoj k učení ženy zaujaly, ovlivnil volbu strategií učení. Obdobně jako po nástupu do zaměstnání se i v této situaci jeví jako efektivní kombinace různých strategií „reprezentující“ aktivní i reaktivní postoj: všechno, co na tom počítači umím, tak jsem se musela naučit sama. Takže bud' jsem začínala od nějakejch obyčejnech postupů a programů, který jsme tam měli, ale pak mě třeba holky [myšleno dcery] něco napověděly, co mám udělat, protože jsem ríkala: "tam se mně něco udělalo, nevím, co s tím“. Tak mi napověděly holky. Pak jsem taky absolvovala nějakej ten kurz, jednodenní vždycky. Tak to mi stačilo, vzpomíná Veronika.

Přestože učení se změnám $\mathrm{v}$ průběhu zaměstnání vyznívá jako učení se v důsledku tlaku dané situace, objevuje se i učení do zásoby. Jen obtížně identifikovatelná hranice mezi oběma způsoby informálního učení souvisí s cíli kariérového rozvoje žen. Pokud ženy nechtějí na dosavadním kariérovém rozvoji nic měnit, zaujímají reaktivní postoj k učení. Obsah informálního učení může být zpětně vnímán i jako učení se do zásoby. Pokud ale mají sklon ke změnám nebo uvažují v intenci permanentního kariérového rozvoje, vykazují aktivní postoj k učení a informální učení v důsledku tlaku vnímají současně i jako učení se do zásoby.

\section{Shrnutí a podněty $k$ diskusi}

Základním předpokladem pro to, abych mohla sledovat vliv informálního učení na řízení kariéry, byla schopnost žen reflektovat své učení. $Z$ dat je patrné, že ženy tuto dovednost mají, a i když jsem si vědoma limitů síly jednotlivých závěrů v důsledku konstrukce výzkumného vzorku, mohu na základě výpovědí sedmi žen podat následující odpovědi na tři dílčí výzkumné otázky.

Kdy se ženy učí? Ženy se učí v období rodičovské dovolené, v období nezaměstnanosti, po nástupu do nového zaměstnání a v souvislosti se změnami obsahu vykonávané práce. Pokud se ženy učily pod tlakem tíživé situace, učení bylo motivováno deficitními motivy. Informální učení v tomto případě ženy považují za instrumentální chování, které má za cíl redukovat deficitní stav jako např. finanční nejistota, nedostatek sociálního kontaktu nebo pocit neužitečnosti. $V$ př́ípadě, že se ženy učily tzv. do zásoby, učení inicioval pocit vnitřního napětí mezi aktuálním a žádoucím stavem, a informální učení lze 
vnímat jako instrumentální chování iniciované motivy růstu, které uspokojuje tzv. seberealizační potřeby ${ }^{7}$ (Nakonečný, 1996, s. 146-147). Ženy z uvedeného vzorku učily z touhy po uspokojení potřeb, ale jednaly spíše jako racionálně kalkulující bytosti než $\mathrm{v}$ důsledku přirozené touhy (potřeby) se učit. Jen ojediněle lze $\mathrm{v}$ datech doložit seberegulační motivy učení založené na dobře zvážených emocích a touhách kariérového rozvoje (srov. Van Dellen, 2012, s. 19-20). Dalším zajímavým výsledkem je, že uvědomění si potřeb a jejich „pozice“ v kariérovém rozvoji vedlo ženy k rozhodnutí o tom, jestli budou potřeby uspokojovat prostřednictvím učení se do zásoby, nebo učením se z nutnosti ( $\mathrm{v}$ důsledku tlaku dané situace).

Jak se ženy učí? Přestože jednotlivé taktiky a strategie učení ženy volí s ohledem na konkrétní situaci a na prostředí, ve kterém učení probíhá, zajímavou roli sehrává taktika (př́ipadně strategie) vyhledávání sociální pomoci a strategie samostudia. Taktiku (případně strategii) vyhledávání sociální pomoci volily ty ženy, které zaujaly reaktivní postoj k učení, a dá se říci, že tyto ženy se informálně učí prioritně ze zkušeností druhých. Pokud ženy využívaly vyhledávání sociální pomoci intuitivně, pak je tato taktika obvykle nasměrovala do kurzů neformálního vzdělávání. Naopak strategii samostudia volí spíše ženy s aktivním postojem $\mathrm{k}$ učení a $\mathrm{v}$ době rodičovské dovolené, v období nezaměstnanosti a $\mathrm{v}$ souvislosti se změnami $\mathrm{v}$ náplni práce ji vnímaly jako žádoucí strategii. V období po nástupu do nového zaměstnání však tuto strategii hodnotí jako volbu z nutnosti a považují ji za nežádoucí.

V průběhu kategorizace dat se ale ukázalo, že pojmy strategie a taktiky učení jsou obtížně identifikovatelné bez podrobných popisů kontextu informálního učení. Na druhou stranu volba strategií (v př́ipadě záměrného) učení je dokladem toho, že ženy své informální učení řídí. Z tohoto úhlu pohledu se výběr strategií učení jeví jako obsah seberegulujícího informálního učení a lze předpokládat, že se ženy díky reflexi seberegulujícího učení učí dál (srov. Nehyba, 2012, s. 50-51). Pokud by ženy dokázaly ve svých př́ibězích reflektovat i to, že své zkušenosti s výběrem strategií učení využívají v nových situacích, což se v našem př́padě nestalo, mohly bychom tvrdit, že informální učení probíhá cyklicky.

Co se ženy učí? I když se konkrétní obsah informálního učení liší, obecně lze konstatovat, že se ženy učí profesním dovednostem (např. šití, účetnictví),

Seberealizační potřeby jsou typické svojí neuspokojitelností, což znamená, že indukují napětí, které je uspokojováno učením, a to vyvolává další snahu po jejich uspokojení. 
které považují za uplatnitelné na trhu práce, a mnohé z nich si osvojují i dovednosti řízení kariéry, které jsou přenositelné do jiných kontextů, než ve kterých vznikly. Zcela výjimečně bylo $\mathrm{v}$ datech zachyceno řízení kariérového rozvoje jako další obsah informálního učení.

\section{Závěr}

Současný akcent na celoživotní učení jedince $\mathrm{v}$ různých fázích života av různých prostředích vyvolává představu,žeby selidéměli učitpermanentně a po celou dobu svého života. Jaká je realita u sedmi žen? Přestože může být diskutována teoretická nasycenost výzkumného vzorku a tím do jisté míry i relevance jednotlivých závěrů, je zřejmé, že se ženy informálně učí $\mathrm{v}$ různých obdobích své kariéry ( $\mathrm{v}$ období rodičovské dovolené, $\mathrm{v}$ období nezaměstnanosti i $\mathrm{v}$ době, kdy byly zaměstnány). Jejich učení ale probíhalo spíše epizodicky než kontinuálně. Ženy se učily v důsledku tlaku (nepříznivé) situace a tento typ informálního učení lze nahlížet jako nástroj uspokojování řady rozmanitých potřeb, jejichž společným jmenovatelem je deficit (např. potřeby finančního zajištění, potřeby sociálního kontaktu, potřeby jistoty). Z hlediska řízení kariérového rozvoje, se ukázalo, že ženy, které se učily pouze v důsledku tlaku tíživých situací, svůj kariérový rozvoj v dlouhodobém horizontu neplánovaly a uvažovaly jen o změně aktuálního stavu. Ženy, které se učily i tzv. do zásoby a snažily se tím uspokojit i tzv. růstové potřeby (Maslow), uvažují o svém kariérovém rozvoji v dlouhodobějším horizontu a informální učení považují za př́mý nástroj kariérového rozvoje.

Obsah informálního učení představují tř̌i oblasti. Ženy se učily profesním dovednostem, dovednostem řízení kariéry a zcela výjimečně i řízení kariérového rozvoje. Zatímco při učení se profesním dovednostem ženy (někdy dobrovolně, jindy z nutnosti) využívaly strategii samostudia, dovednostem řízení kariéry (jako např. organizace času, sebeprezentace, hledání zaměstnání) se učily spíše spontánně. $V$ některých případech se učení dovednostem řízení kariéry stalo „vedlejším produktem“ učení se profesním dovednostem.

Právě popsané zkoumání informálního učení žen vyjevilo i několik bílých míst (např. téma vztahů mezi učením a vnímáním kariéry či kariérového rozvoje, téma profesní identity a její posilování nebo ztráty, téma využívání dovedností řízení kariéry za účelem kariérového rozvoje), která čekají na své objevení v dalších výzkumných šetřeních. 


\section{Literatura}

Australian Blueprint for Career Development. Trial Version. (2006). Dostupné z http://www. dest.gov.au/NR/rdonlyres/B2B0AACE-D719-48AB-8A42-D78203FD4F0D/10560/ BlueprintTrialVersion.pdf

Hartl, P., \& Hartlová, H. (2010). Velký psychologický slovník. Praha: Portál.

Hager, P. (2001). Lifelong learning and the contribution of informal learning. In International handbook of lifelong learning (s. 79-92). Dordrecht, Boston, London: Kluwer Academic Publisher.

Hendl, J. (2005). Kvalitativní výzkum. Základní metody a aplikace. Praha: Portál.

Illeris, K. (Ed.). (2009). Contemporary theories of learning. London, New York: Routledge Taylor $\&$ Francis Group.

Jarvis, P. S. (2003). Career management paradigm shift: Prosperity for citizens, windfalls for governments. Dostupné z http://www.choixdecarriere.com/pdf/6573/Jarvis\%282003\% 29.pdf

Kirovová, I. (2007). Kariéra v souvislosti s přechodem k postindustrialismu. Ostrava: Vysoká škola báňská, Technická univerzita Ostrava.

Klasifikace zaměstnání KZAM-R. (2010). Dostupné z

http://www.czso.cz/csu/klasifik.nsf/i/kzam_systematicka_cast

Kulič, V. (1992). Psychologie ř́zeného učení. Praha: Academia.

Marinková, H., \& Stretti, M. (2009). Formální vzdělávání, neformální vzdělávání, informální učení. In J. Průcha (Ed.), Pedagogická encyklopedie (s. 247-251). Praha: Portál.

Nehyba, J. (2012). Tři inspirace od Petera Jarvise. Studia paedagogica, 17(1), 37-58.

Löwe, H. (1977). Úvod do psychologie učení dospělých. Praha: SNP.

Mareš, J. (1998). Styly učení žáků a studentů. Praha: Portál.

Nakonečný, M. (1996). Motivace lidského chování. Praha: Academia.

Palán, Z. (2002). Lidské zdroje: výkladový slovník. Praha: Academia.

Pätzold, H. (2011). Learning and teaching in adult education. Contemporary theories. Opladen: Barbara Budrich Publishers \& Farmington Hills, MI.

Průcha, J., \& Veteška, J. (2012). Andragogický slovník. Praha: Grada.

Rabušicová, M., Kamanová, L., \& Pevná, K. (2011). O mezigeneračním učení. Brno: MU.

Rabušicová, M., \& Rabušic, L. (2008). Dospělí a informální učení. In M. Rabušicová \& L. Rabušic (Eds.), Učíme se po celý život? O vzdělávání dospělých v České republice (s. 77-95). Brno: Masarykova univerzita.

Švaříček, R. (2007). Biografický design. In R. Švaříček \& K. Šed'ová, et al., Kvalitativní výzkum v pedagogických vědách (s. 126-141). Praha: Portál.

Toric, B. (2007). 'Boundaryless'career - Implications for individual and organisational learning. München: GRIN Verlag.

Sultana, R. G. (2012). Learning career management skills in Europe: A critical review. Journal of Education and Work, 25(2), 225-248. Dostupné z http://dx.doi.org/10.1080/13639080.2 010.547846.

Van Dellen, T. (2012). Celoživotní učení a chut' se učit. Studia paedagogica, 17(1), 15-35.

Vzdělávání dospělých v číslech. (2012). Dostupné z http://www.czso.cz/csu/2012edicniplan. $\mathrm{nsf} / \mathrm{p} / 3313-12$. 


\title{
Autorka
}

Mgr. Lenka Hloušková, Ph.D., Masarykova univerzita, Filozofická fakulta, Ústav pedagogických věd, Arna Nováka 1, 60200 Brno, e-mail: hlouskov@phil.muni.cz

\section{Informal learning within the career development of women}

\begin{abstract}
The aim of this text is to describe how informal learning influences the career development of women. Answer to the above mentioned question follows from a qualitative study within a research study on the topic: The needs of adults in relation to the building of their careers and how to satisfy these through career counselling and guidance services. Qualitative approach was implemented as biographic research with the use of the life story method. For the purpose of this text, we used a sample of seven women of different ages, the same degree of education, with at least one-year-work experience and with different types of changes in their careers. The data suggest that women learn informally either due to the pressure of a situation or "for the future". If women learn as a result of the pressure of the situation, informal learning represents a tool for satisfying needs that are perceived as deficit. In fact, these women don't plan their career development in a long-term perspective and from the point of view of career building, informal learning becomes a tool for changing the current state. In case that women learn for the future, via learning they try to satisfy needs which can be regarded (according to Maslow) as the self-realization needs. These women plan their career development and this is why it is possible to consider informal learning as a direct tool for their career development.
\end{abstract}

Keywords: informal learning, career, career development, life story

\section{Diagnostika a intervenční postupy ve školní psychologii}

Fakulta humanitních studií Univerzity Tomáše Bati ve Zlíně, Asociace školní psychologie SR a ČR a Národní ústav pro vzdělávání Praha pořádají mezinárodní konferenci Diagnostika a intervenční postupy ve školní psychologii. Jubilejní konference je organizována u příležitosti 20. výročí první zlínské konference a uskuteční se ve dnech 30.-31. 8. 2013 ve Zlíně. Konference je určena školním a poradenským psychologům, výchovným poradcům, školním speciálním pedagogům, pracovníkům vysokých škol a rezortních výzkumných ústavů, učitelům základních a středních škol, ředitelům škol, pracovníkům školní inspekce i vysokoškolským studentům. 